\title{
PROBLEMATIKA NIKAH SIRI, NIKAH ONLINE DAN TALAK SIRI SERTA IMPLIKASI HUKUMNYA DALAM FIKIH NIKAH
}

\author{
Oleh: Andi Muhammad Akmal, Mulham Jaki Asti \\ E-mail:andi.akmal@uin-alauddin.ac.id \\ Fakultas Syariah dan Hukum UIN Aluddin Makassar
}

\begin{abstract}
Abstrak
Penelitian ini bertujuan untuk menganalisis eksistensi nikah siri, nikah online dan talak siri dalam hukum Islam dan hukum nasional serta mplikasi hukum nikah siri, nikah online dan talak siri dalam Fikih Nikah. Jenis penelitian ini adalah penelitian pustaka dengan pendekatan metode kualitatif normative yuridis. Data dikumpulkan melalui dokumen peraturan perundangundangan terkait pernikahan dan referensi sumber dalam kajian hukum Islam. Hasil penelitian menunjukkan bahwa keabsahan suatu pernikahan dalam kajian hukum Islam, harus memenuhi syarat dan rukun sebagaimana telah dijelaskan sebelumnya Walaupun para fuqaha berbeda pandangan dalam memberikan penjelasan terkait dengan ketentuan dalam pernikahan, namun yang paling prinsip mereka sepakat bahwa syarat dan rukun nikah sebagaimana telah dijelaskan diatas merupakan syarat mutlak untuk sahnya suatu pernikahan, termasuk pencatatatan pernikahan. Selain itu, perlu dipertimbangkan dan dikaji lebih jauh tentang nikah online ini. Bahwa unsur kejelasan dan ketepatan dari kedua calon mempelai, wali nikah dan saksi, harus terpenuhi. Hal tersebut untuk menghindari penipuan, agar terbagun maslahat kedua belah pihak.
\end{abstract}

Kata Kunci : Nikah Siri; Nikah Online; Talak Siri

\section{PENDAHULUAN}

Manusia adalah makhluk ciptaan Allah SWT yang sempurna. Kesempurnaan manusia dapat dilihat dari bentuk tubuh yang terlihat secara jelas, organ-organ tubuh yang bekerja dan tertata sedemikian rupa, anugerah yang membedakannya dengan makhluk lain yaitu akal digunakan untuk berpikir dan berkomunikasi. Allah swt. menganugerahi akal pikiran sebagai salah satu kesempurnaan tentu ada hikmah dibalik penganugerahan tersebut yaitu amanah dan anugrah dari Allah swt.

Manusia hidup di dunia ini walaupun diberi kesempurnaan penciptaan tetapi manusia juga butuh manusia lain untuk mempertahankan eksistensinya dan yang utama menjaga bumi ini agar tetap harmonis serta terjaga sebagaimana yang telah diamanahkan Allah SWT kepada manusia. Salah satu upaya untuk menjaga eksistensi manusia di bumi, dengan melaksanakan perkawinan. Manusia berketurunan dan melahirkan generasi bertujuan menjadi pemelihara bumi agar bumi dapat ditempati manusia dengan layak.

Pernikahan juga bertujuan memberikan ketenangan terhadap satu sama lain. Pasangan laki-laki dan perempuan yang bersatu akan memberikan ketenangan dan kenyamanan dalam menjalankan hidupnya di dunia serta menghantarkan manusia dapat mengabdi kepada Allah swt. dengan baik. Dikarenakan perkawinan adalah 
perjanjian penyatuan dua manusia menjadi satu jiwa, perlu diadakan aturan yang menjaga perjanjian tersebut agar tetap kukuh baik oleh agama maupun lembaga Negara. Walaupun pelaksanaan telah diatur dalam agama juga diatur oleh negara, masih terdapat banyak problem dalam pelaksanaan perkawinan seperti permasalahan nikah siri, nikah online dan talak siri.

Pencatatan akad nikah adalah salah satu syarat dalam melangsungkan perkawinan dengan tujuan negara dapat memberikan perlindungan kepada pasangan, terhadap akad yang telah dilaksanakan. Maka dari itu pencatatan perkawinan adalah hal yang sangat penting dipahami dan dilaksanakan dalam melangsungkan akad perkawinan.

Pentingnya pencatatan perkawinan di lembaga negara masih sering diabaikan masyarakat sehingga banyak terjadi nikah siri. Pernikahan siri adalah pernikahan yang dilaksanakan sesuai dengan Fikih Nikah yang berlaku secara global, namun tidak tercatat di Kantor Urusan Agama setempat. Perkawinan ini dilangsungkan secara sembunyi tanpa adanya publikasi kepada negara.

Terdapat permasalahan lain seperti nikah online. Situasi pernikahan tersebut merupakan dampak dari perkembangan teknologi informasi dan komunikasi yang sangat pesat memudahkan manusia melakukan sesuatu termasuk dalam melangsungkan akad perkawinan. Adanya teknologi seperti bertukar pesan informasi dan berkomunikasi seperti telekonferensi dan pesan video menjadi alternatif melangsungkan perkawinan tanpa harus berada di tempat yang sama.

Demikian pula, kasus Talak siri, yang menjatuhkan talak kepada pasangan tanpa melalui proses Lembaga Negara, Kantor Pengadilan Agama setempat. Hal tersebut terjadi, salah satu indkatornya merupakan dampak dari nikah dengan tidak tercatatnya akad nikah di lembaga negara. Problematika mengenai perkawinan dan dampaknya menarik untuk dibahas dalam tulisan ini khususnya mengenai nikah siri, nikah online, dan talak siri.

\section{METODE PENELITIAN}

Jenis penelitian ini adalah penelitian pustaka dengan pendekatan metode kualitatif normative yuridis. Data dikumpulkan melalui dokumen peraturan perundangundangan terkait pernikahan dan referensi sumber dalam kajian hukum Islam. Data dianalisis dengan menggunakan analisis Miles dan Hubberman yang berakhir pada kesimpulan hukum terkait nikah siri, talak siri dan nikah online.

\section{HASIL \& PEMBAHASAN}

\section{A. Eksistensi Nikah Siri, Talak Siri dan Nikah Online dalam Hukum Islam dan Hukum Nasional}

a. Nikah Siri

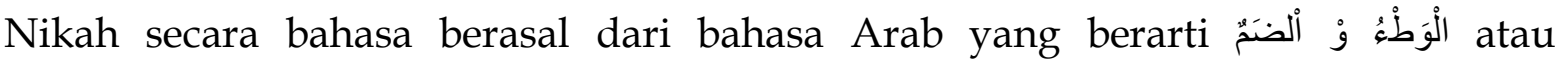
berkumpul atau bercampur dapat diartikan dengan akad atau ikatan karena proses pernikahan terdiri dari ijab dan qabul. Siri adalah istilah yang berasal dari bahasa Arab 
dan menjadi bahasa serapan dalam bahasa Indonesia. Siri dalam bahasa Arab yaitu sirran berarti rahasia. Istilah dari kata siriyun yaitu berbuat sesuatu secara rahasia .

Kamus Besar Bahasa Indonesia mengartikan nikah siri yairtu pernikahan yang tidak melalui Kantor Urusan Agama (KUA). Oleh karena itu pasangan suami istri tersebut tidak memiliki surat nikah yang sah di mata negara hanya disaksikan oleh saksi tetapi tidak terdaftar di KUA. Nikah Siri menurut M. Zuhdi Muhdhar adalah pernikahan yang berlangsung tanpa sepengetahuan Petugas Pencatat Nikah (PPN) atau Kantor Urusan Agama (KUA) karenanya, tidak memiliki dokumen nikah yang sah.

Nikah siri adalah perkawinan yang dilaksanakan oleh pihak mempelai laki dan perempuan, wali nikah, saksi tetapi tidak dipublikasikan kepada lembaga negara dalam hal ini Pegawai Pencatat Nikah (PPN) atau Kantor Urusan Agama (KUA). Oleh karena itu perkawinan siri tidak diakui oleh negara dan tidak mempunyai kekuatan hukum.

Ada beberapa indikator untuk mengetahui bahwa perkawinan tersebut tidak dikategorikan siri yaitu: Subjek hukum akad nikah, yaitu calon mempelai suami dan calon mempelai istri serta adanya wali nikah dan dua orang saksi, Kepastian hukum pernikahan yaitu disaksikan oleh Pegawai Pencatat Nikah. Resepsi atau walimah 'alarusy, yaitu membuat acara bertujuan untuk memperlihatkan kepada khalayak luas bahwa telah terjadi akad nikah antara suami dan istri secara resmi.

Tiga indikator ini pastinya terlihat dalam pernikahan yang dilakukan berdasarkan hukum agama Islam dan hukum nasional. Untuk mengetahui lebih spesifik bentuk nikah siri, dapat diamati pada indikator sebagai berikut:

1) Pernikahan tidak memenuhi rukun dan syarat nikah sesuai dengan ketentuan dalam agama Islam yakni; akad nikah yang terdiri dari calon suami, calon istri, wali nikah, dan dua orang saksi.

2) Pernikahan tidak memenuhi persyaratan yang dibuat oleh pemerintah untuk memperoleh kepastian hukum dari pernikahan yakni hadirnya Pegawai Pencatat Nikah (PPN) saat akad nikah berlangsung.

3) Pernikahan tidak melaksanakan walimah al ursy. Padahal sesuatu yang dilaksanakan untuk menunjukkan kepada masyarakat luas bahwa di antara kedua calon suami-istri telah menjadi suami-istri.

Pernikahan yang sesuai dengan tuntunan hukum agama dan ketentuan hukum negara adalah upaya untuk melindungi perkawinan tersebut dari hal-hal yang akan merugikan para pelakunya. Ketentuan agama menunjukkan bahwa pernikahan tidak boleh dilaksanakan secara asal tanpa adanya unsur dan pihak yang menjamin perkawinan tersebut sah di mata agama. Sedangkan adanya ketentuan dari negara memberikan perlindungan terhadap pihak-pihak yang ada di dalamnya yaitu suami, istri, maupun keturunan yang dihasilkan dalam pernikahan tersebut.

Memperbincangkan nikah siri ditinjau dari aspek hukum positif, maka pendekatan yang digunakan adalah perangkat hukum yang telah diatur dan diakui oleh sistem perundangan nasional Indonesia. Sedikitnya ada tiga perangkat hukum yang mengatur tentang pernikahan di Indonesia, yaitu Undang-Undang Nomor 1 Tahun 1974 tentang 
Perkawinan, Kitab Undang-Undang Hukum Perdata (KUHPer) dan Kompilasi Hukum Islam (KHI). Secara umum, dalam perspektif hukum Islam, nikah siri cenderung diperbolehkan dalam literaratur Fikih Nikah, asalkan memenuhi ketentuan pernikahan. Sebaliknya, dalam hukum positif nasional, nikah siri telah ditegaskan sebagai pernikahan yang ilegal. Bahkan, dalam perundang-undangan nasional tentang pernikahan, baik dalam UU Perkawinan maupun dalam KHI, tidak ada satu katapun yang menyebutkan nikah siri. Yang digunakan dan yang dibahas adalah sistem pernikahan secara umum. Hal ini menunjukkan bahwa nikah siri tidak dianggap dan tidak diperhitungkan dalam hukum perkawinan nasional. Nikah siri lebih dikenal dalam hukum agama dan adat istiadat.

Sebagaimana disebutkan dalam Undang-Undang perkawinan Nomor 1 Tahun 1974 bahwa: "Perkawinan adalah sah apabila dilakukan menurut hukum masing-masing agama dan kepercayaannya Tiap-tiap perkawinan dicatat menurut Perundangan yang berlaku." Tetapi di samping itu ada keharusan pencatatan menurut peraturan perundang-undangan yang berlaku. Pencatatan setiap perkawinan sama halnya dengan pencatatan suatu peristiwa hukum dalam kehidupan seseorang misalnya kelahiran, kematian yang dinyatakan dalam suatu akta resmi (Surat Keterangan) yang dimuat dalam daftar pencatatan yang disediakan khusus untuk itu. Menurut Undang-Undang Perkawinan No. 1 Tahun 1974, perkawinan yang sah adalah perkawinan yang dicatatkan. Pasal 2 ayat 2 menyatakan bahwa "Tiap-tiap perkawinan dicatat menurut peraturan perundang-undangan yang berlaku". Di dalam pasal 1863 HIR juga dinyatakan bahwa catatan atau bukti yang diakui keabsahannya, tidak saja dalam akad nikah, tetapi juga dalam segala bentuk perjanjian perkawinan.

Pencatatan perkawinan menandakan perkawinan menjadi resmi di mata hukum negara. Perkawinan dapat mempunyai akibat hukum terhadap semua pihak. Suami dan isteri diberikan bukti otentik berupa surat nikah (kutipan akta nikah) dan memperoleh perrlindungan hukum bagi suami isteri, anak-anaknya, keluarganya dan pihak lainnya dalam hubungan hukum dan pergaulan hidup di masyarakat.

Perkawinan dalam Kompilasi Hukum Islam terdapat dalam beberapa pasal, di antaranya adalah Pasal 4: "Perkawinan adalah sah, apabila dilakukan menurut hukum Islam sesuai dengan pasal 2 ayat (1) UU No. 1 tahun 1974 tentang perkawinan". Pasal 5 ayat (1): "Agar terjamin ketertiban perkawinan bagi masyarakat Islam setiap perkawinan harus dicatat". Pasal 5 ayat (2): "Pencatatan Perkawinan tersebut terdapat pada ayat (1), dilakukan oleh Pegawai Pencatat Nikah (PPN) sebagaimana yang diatur dalam UU No. 22 tahun 1946 jo UU No. 32 tahun 1954”. Pasal 6 ayat (1): “Untuk memenuhi ketentuan dalam pasal 5, setiap perkawinan harus dilangsungkan dihadapan dan di bawah pengawasan Pegawai Pencatat Nikah." Pasal 6 ayat (2): "Perkawinan yang dilakukan diluar pengawasan Pegawai Pencatat Nikah tidak mempunyai kekuatan Hukum". Pasal 7 ayat (1): "Perkawinan hanya dapat dibuktikan dengan Akta Nikah yang dibuat oleh Pegawai Pencatat Nikah".

Berdasarkan Undang Undang RI. Nomor 1 Tahun 1974 Tentang Perkawinan dan Inpres RI. No. 1 Tahun 1991 Tentang Kompilasi Hukum Islam bahwa eksistensi nikah siri tidak valid serta tidak sah. Hal tersebut dapat dilihat pada pasal 2 ayat (1) UU RI 
Nomor 1 tahun 1974 dan Kompilasi Hukum Islam (KHI) pasal 4. Subtansi perkawinan pada peraturan perundang undangan tersebut dapat dipahami sebagai hal yang lebih urgent mengenai kelangsungan hidup manusia sebagai mahluk sosial, yang hidup dalam payung negara maka pemerintah mewajibkan untuk pencatatan perkawinan. Penetapan pemerintah dengan peraturan tersebut untuk kemaslahatan warga negara.

Nikah siri dalam Hukum Perkawinan Nasional adalah perkawinan yang tidak sesuai, karena selain tidak adanya kekuatan hukum untuk melindungi hak dan kewajiban suami istri juga tidak adanya keterangan (akta nikah) telah melangsungkan perkawinan yang diakui oleh negara sebagai unsur yang dapat memastikan terjaminya hak dan kewajiban antar suami istri dan orang yang terlibat di dalamnya baik secara langsung atau tidak langsung.

Para ulama telah sepakat bahwa akad nikah itu baru bisa dilaksanakan setelah terpenuhinya syarat dan rukun nikah, antara lain yaitu; Adanya calon pengantin lakilaki dan calon pengantin perempuan. Calon pengantin tersebut kedua-duanya telah dewasa dan berakal. Adanya persetujuan antara kedua calon pasangan pengantin. Harus ada wali bagi calon mempelai perempuan. Harus ada mahar (maskawin) dari calon mempelai laki-laki. Harus dihadiri sekurang-kurangnya dua orang saksi laki-laki yang adil; Adanya pelaksanaan ijab dan qabul.

Demikian juga sebagaimana yang diungkapkan oleh, Syekh Jaad Al Haq Ali Jaad Al Haq, membagi ketentuan yang mengatur pernikahan kepada dua kategori, Peraturan syara' yaitu; Peraturan yang menentukan sah atau tidak sahnya sebuah pernikahan. Peraturan ini adalah peraturan yang ditetapkan oleh syariat Islam seperti yang telah dirumuskan oleh ahli fiqih dari berbagai mazhab yang intinya, bahwa suatu keharusan adanya ijab qabul dari masing-masing dua orang yang berakad yang diucapkan pada majelis yang sama, dengan menggunakan lafaz yang menunjukkan telah terjadi ijab dan qabul yang diucapkan oleh masing-masing dari dua oarang yang mempunyai kecakapan untuk melakukan akad menurut syara' serta dihadiri oleh dua orang saksi yang telah baligh, berakal beragama Islam dan mendengarkan sendiri secara langsung lafaz ijab dan qabul tersebut.

Peraturan yang bersifat tawsiqy; (pencatatan), peraturan tambahan yang dimaksudkan agar pernikahan di kalangan umat Islam, teregistrasi, tercatat dan resmi. Oleh karena itu, hendaknya pernikahan tersebut tercatat secara resmi yang dikeluarkan oleh pihak yang berwenang. Dengan tujuan agar kewenangan lembaga atau institusi sebagaimana yang telah dikemukakan, dapat memberikan perlindungan bagi umat Islam dari adanya upaya negatif dari pihak yang tidak bertanggung jawab. Misalnya, sebagai antisipasi dari adanya pengingkaran akad nikah oleh suami di kemudian hari. Walaupun pada dasarnya dapat dilindungi dengan adanya saksi-saksi tetapi sudah tentu akan lebih dapat dilindungi lagi dengan pencatatan resmi di lembaga yang berwenang untuk itu.

Dapat dipahami berdasarkan penjelasan dan keterangan tersebut, bahwa keabsahan suatu pernikahan dalam kajian hukum Islam, harus memenuhi syarat dan rukun sebagaimana telah dijelaskan sebelumnya Walaupun para fuqaha berbeda pandangan dalam memberikan penjelasan terkait dengan ketentuan dalam pernikahan, 
namun yang paling prinsip mereka sepakat bahwa syarat dan rukun nikah sebagaimana telah dijelaskan diatas merupakan syarat mutlak untuk sahnya suatu pernikahan, termasuk pencatatatan pernikahan.

\section{b. Nikah Online}

Nikah online adalah pernikahan yang pelaksanaannya menggunakan via teknologi dikarenakan jarak terpisah antara para pihak yang melangsungkan perkawinan. Dikarenakan adanya situasi yang tidak memungkinkan diadakannya pernikahan dengan cara bertemu langsung secara tatap muka dengan salah satu pihak dalam perkawinan, dengan adanya teknologi video call atau video teleconference yang dapat menyampaikan suara dan gambar secara realtime melalui jaringan internet.

Ijab kabul secara online dapat dilaksanakan dengan memasang proyektor ke layar besar untuk menampilkan pihak-pihak yang wajib ada dalam melangsungkan perkawinan. Hal ini dilangsungkan agar membuktikan dan dapat disaksikan semua orang sebagaimana akad yang dilangsungkan secara langsung serta adanya alat pengeras suara agar seluruh pihak dapat mendengar dengan jelas ijab kabul sebagaimana pernikahan langsung pada umumnya. Pelaksanaan nikah online perlu dilengkapi dengan aturan yang jelas. Para ulama tidak mempermasalahkan metode pelaksanaan nikahnya tetapi adanya kesinambungan antara pernyataan ijab dan kabul dari para pihak yang melangsungkan perkawinan tanpa adanya kesamaran dan penafsiran lain.

Harus dipahami bahwa nikah online adalah salah satu dari sekian alternatif dalam melangsungkan kegiatan hukum. Perkembangan teknologi memberikan jalan untuk memudahkan pelaksanaan suatu kegiatan hingga kegiatan tersebut dapat dilaksanakan dengan baik dan tetap dalam ketentuan umum yang harus dipatuhi dalam melangsungkan suatu kegiatan khususnya kegiatan hukum perkawinan yang menyatukan kedua jiwa raga dan juga ikut menyatukan keluarga.

Perkembangan teknologi informasi akhir-akhir ini tidak dapat dipungkiri lagi keberadaannya, pasalnya sampai ada pihak yang melakukan ijab Kabul melalui media elektronik seperti telepon, video call, teleconference, whatsapp atau media lainnya, dengan berbagai alasan, secara faktual alat komunikasi modern yang dipergunakan untuk melakukan ijab kabul terbagi menjadi dua macam pertama, alat-alat yang memindah suara dan kata-kata, kedua, alat alat yang memindah tulisan.

Normalnya proses ini dilakukan dalam satu majelis, artinya ijab kabul dilakukan pada saat yang bersamaan dan disaksikan oleh dua orang saksi. Abdul Moqsith Ghazali, peneliti The Wahid Institute mengistilahkan ijab kabul dalam satu majelis tersebut artinya, dalam satu ruang dan waktu. Berkenaan dengan konsep dasar tentang keabsahan suatu perkawinan yang dilaksanakan menurut hukum perkawinan nasional, hal itu tertuang pada rumusan Pasal 2 ayat (1) dari Undang-Undang Perkawinan dengan redaksi "perkawinan adalah sah, apabila dilakukan menurut hukum masingmasing agamanya dan kepercayaannya itu." Pasal 4 KHI dinyatakan "Perkawinan 
adalah sah, apabila dilakukan menurut hukum Islam sesuai dengan Pasal 2 ayat (1) Undang-undang Perkawinan."

Pengetahuan tentang keabsahan perkawinan akan lebih optimal apabila memahami dengan jelas makna kata "perkawinan" dalam konsep Undang-Undang Perkawinan dan juga KHI. Hukum positif Indonesia memang tidak ada hukum yang mengatur secara formal, sebagai bahan pertimbangan peraturan hukum dari Perdata Mesir yang berpendapat: "bahwa ijab Kabul menggunakan telepon atau melalui alat apa saja yang menyamainya disamakan dengan ijab kabul yang bertemu langsung ditinjau dari segi waktunya, dan disamakan dengan akad orang yang tidak bertemu ditinjau dari segi tempatnya". Berdasarkan hal tersebut dapat dilihat bahwa menurut pandangan hukum positif di Mesir, pernikahan melalui online hukumnya disamakan dengan ijab kabul orang yang bertemu langsung mengenai aspek waktunya, namun problemanya dengan tempat pelaksanaan ijab kabul bila dibandingkan dengan orang bertemu langsung, mengalami perbedaan.

Keabsahan suatu redaksi dapat dipastikan dengan cara mendengarkannya, akan tetapi, bahwa redaksi itu benar-benar asli diucapkan oleh kedua orang yang sedang melakukan akad, kepastiannya hanya dapat dijamin dengan jalan melihat para pihak yang mengucapkan itu dengan mata kepala. Pendapat ini yang dipegangi kalangan ulama ulama mujtahid, terutama kalangan syafi'iyah.

Kabul yang langsung diucapkan setelah ijab diucapkan wali, adalah di antara halhal yang menunjukkan kerelaan calon suami, sebaliknya, adanya jarak waktu yang memutuskan ijab kabul, dapat jadi menunjukkan bahwa calon suami tidak lagi sepenuhnya rela untuk mengucapkan kabul dan wali nikah dalam jarak waktu tersebut, bisa saja pendiriannya berubah, maka untuk lebih memastikan bahwa masing masing masih dalam kerelaannya, kesinambungan antara ijab kabul disyaratkan.

Ijab kabul disyaratkan terjadi dalam satu majelis, tidak disela-sela dengan pembicaraan lain atau perbuatan-perbuatan yang menurut adat kebiasaan dipandang mengalihkan akad yang sedang dilakukan, namun, tidak disyaratkan antara ijab kabul harus berhubungan langsung. Jika setelah ijab dikatakan oleh wali mempelai perempuan atau wakilnya, tiba tiba mempelai laki-laki berdiam beberapa saat tidak mengatakan kabul, baru setelah itu menyatakan kabulnya, ijab kabul dipandang sah. Pendapat ini dikemukakan oleh mazhab Hanafi dan Hanbali. Konsekuensi dari pandangan ini, dua orang saksi tidak mesti dapat melihat dengan mata kepala pihak pihak yang melakukan akad nikah.

Satu majelis disyaratkan, bukan saja untuk menjamin kesinambungan antara ijab kabul, tetapi sangat erat hubungannya dengan tugas dua orang saksi yang menurut pendapat ini, harus dapat melihat dengan mata kepalanya bahwa ijab kabul itu benar diucapkan oleh kedua orang yang melakukan akad dan dihadiri oleh dua orang saksi, sebagai bagian dari rukun nikah. Tugas dua orang saksi itu, seperti disepakati para ulama, terutama untuk memastikan secara yakin akan keabsahan ijab kabul, baik dari segi redaksinya, maupun dari segi kepastian bahwa ijab kabul itu adalah diucapkan oleh kedua belah pihak. 
Ijab kabul disyaratkan terjadi dalam satu majelis, tidak disela-sela dengan pembicaraan lain atau perbuatan yang menurut adat kebiasaan dipandang mengalihkan akad yang sedang dilakukan. Namun, tidak disyaratkan antara ijab kabul harus berhubungan langsung. Keabsahan suatu redaksi dapat dipastikan dengan cara mendengarkannya, akan tetapi, bahwa redaksi itu benar- benar asli diucapkan oleh kedua orang yang sedang melakukan ijab kabul, kepastiannya hanya dapat dijamin dengan jalan melihat para pihak yang mengucapkan itu dengan mata kepala. Pendapat ini yang dipegangi (mu'tamad) di kalangan ulama mujtahid, terutama kalangan syafi'iyah. Keabsahan kesaksian ijab kabul, ada satu target keyakinan yang harus diwujudkan oleh para saksi dalam kesaksiannya. Meskipun suatu redaksi dapat diketahui siapa pembicaranya dengan jalan mendengar suara saja, namun bobotnya tidak akan sampai ke tingkat keyakinan apabila dilihat pengungkapannya dengan mata kepala, sedangkan dalam ijab kabul, tingkat keyakinan yang disebut terakhir inilah yang diperlukan. Pandangan tersebut sangant erat hubungannya dengan sikap para ulama terutama kalangan Syafi'iyah yang selalu bersikap hati-hati (ihtiyat) dalam menetapkan suatu hukum, utamanya dalam masalah akad nikah, yang berfungsi sebagai penghalalan sesuatu diharamkan sebelumnya.

Kesaksian harus didasarkan atas pendengaran dan penglihatan, menurut pandangan ini ijab kabul melalui surat tanpa mewakilkan dianggap tidak sah, oleh karena itu Imam Nawawi dalam kitabnya al-Majmu menjelaskan, apabila salah seorang dari dua belah pihak yang melakukan akad nikah mengucapkan ijabnya dengan jalan berteriak dari tempat yang tidak dapat dilihat, dan teriakan itu didengan oleh pihak lain, dan pihak yang terakhir ini langsung mengucapkan kabulnya, akad nikah seperti itu tidak sah.

Namun di sisi lain, perlu dipertimbangkan dan dikaji lebih jauh tentang nikah on line ini. Bahwa unsur kejelasan dan ketepatan dari kedua calon mempelai, wali nikah dan saksi, harus terpenuhi. Hal tersebut untuk menghindari penipuan, agar terbagun maslahat kedua belah pihak.

\section{c. Talak Siri}

Talak adalah istilah hukum Islam yang berarti berpisah atau memutuskan hubungan antara suami dan istri. Para ulama mazhab mendefinisikan talak dengan pengertian yang berbeda-beda. Mazhab Maliki mendefinisikan talak adalah sifat hukum yang menyebabkan gugurnya kehalalan suami istri. Mazhab Hanafi dan Hambali mendefinisikan talak yaitu pelepasan ikatan perkawinan secara langsung atau di masa yang akan datang. Mazhab Syafi'i mendefinisikan talak sebagai pelepasan akad nikah dengan lafaz talak atau yang semakna dengan lafaz talak.

Mengenai talak siri yaitu bentuk talak yang dilakukan hanya berdasarkan hukum agama atau adat tetapi tidak diumumkan kepada pihak yang berwenang mengetahui atau tidak dicatatkan secara resmi di Kantor Pengadilan Agama setempat. Talak siri dikategorikan sebagai talak yang hanya diucapkan secara sepihak sehingga talak siri hanya akan putus menurut hukum agama (fikih global) dan atau hukum adat. Jadi, 
talak siri adalah talak yang dijatuhkan untuk memutuskan hubungan suami istri dengan cara tidak dipublikasikan. Talak siri tidak sah di mata negara karena talak siri tidak dipublikasikan kepada pihak yang berwenang menangani persoalan talak. Maka dari itu talak dan seluruh dampak hukumnya tidak dapat dipertanggungjawabkan tanpa adanya publikasi kepada pihak yang berwenang, dengan bukti Akte Cerai dari Institusi yang berwenang.

Keabsahan hukum ikrar talak di luar Pengadilan Agama, menurut hukum fikih berbeda-beda sesuai dengan pemahaman masing-masing fuqaha, yang mereka ambil dari dalil Al-Qurean dan Al-Hadis. Dengan demikian perbedaan tersebut terdapat pada hukum fikih yang didasari oleh perbedaan metode istinbat hukum yang mereka gunakan.

Hukum fikih merupakan bagian dari hukum Islam, sehingga dapat dikatakan bahwa perbedaan keabsahan hukum ikrar talak di luar pengadilan terdapat pada bagian hukum Islam. Sebagaimana yang dimuat dalam kitab-kitab fikih klasik, keabsahan hukum ikrar talak di luar pengadilan berkaitan dengan:

1) Perlunya atau tidaknya keterlibatan pengadilan atau putusan hakim dalam menentukan keabsahan ikrar talak oleh suami.

2) Perbedaan pendapat tentang hukum mempersaksian ikrar talak suami.

3) Terpenuhinya syarat dan rukun ikrar talak.

4) Perbedaan pendapat terhadap hadis yang menyatakan jatuhnya talak, nikah dan rujuk meskipun main-main.

5) Perbedaan pendapat tentang keabsahan talak tiga dalam satu majlis/ talak tiga sekaligus.

Perbandingan dengan keabsahan ikrar talak menurut peraturan perundangundangan, adalah sebagai berikut:

1) Putusnya perkawinan/perceraian harus dilaksanakan di depan sidang pengadilan, baik izin talak oleh suami, terlebih gugat cerai istri.

2) Perceraian di muka sidang pengadilan tentu disaksikan oleh para hakim pengadilan, setelah putusan izin talak.

3) Proses sidang pengadilan tidak sekedar terpenuhinya syarat dan rukun talak, lebih utama lagi harus adanya alasan-alasan perceraian sebagimana dicantumkan dalam pasal 19 PP N0. 9 tahun 1975.

4) Dalam peraturan perundang-undangan tidak mengenal istilah ketidakseriusan dalam ikrar talak, nikah dan rujuk.

5) Dalam peraturan perundang-undangan secara otomatis tidak dapat berlaku talak tiga (talak ba' in) dalam satu majelis.

Perbedaan pendapat ulama fikih tentang keabsahan ikrar talak terkait keterlibatan Pengadilan Agama dalam ikrar talak oleh suami, berdasarkan pandangan bahwa talak adalah hak suami, sehingga kapan dan di mana pun suami menggunakan haknya, maka sahlah apa yang dia tunaikan. Hal ini menurut Fikih Global. 
Tentang keabsahan ikrar talak, Pasal 115 KHI menguatkan pasal 39 ayat (1) UU No. 1 Tahun 1974, dan pasal 65 UU No. 7 tahun 1989 tentang Peradilan Agama, jo undangundang Nomor 3 Tahun 2006 tentang Perubahan UU No. 7 Tahun 1989 jo undangundang Nomor 50 tentang perubahan kedua atas UU Nomor 7 Tahun 1989 yang menyebutkan: "Perceraian hanya dapat dilakukan di depan sidang pengadilan setelah pengadilan tersebut berusaha dan tidak berhasil mendamaikan kedua belah pihak", Pasal $116 \mathrm{KHI}$ memuat alasan-alasan yang menyebabkan terjadinya perceraian, sebagaimana disebutkan dalam pasal 19 PP No. 9 /1975 ditambah dengan alasan suami melanggar taklik talak dan peralihan agama atau murtad yang menyebabkan terjadinya ketidakrukunan dalam rumah tangga. Semestinya alasan karena murtad memang sudah menjadi keniscayaan yang memutuskan pernikahan, karena tidak diperbolehkannya berbeda agama dalam penikahan hukum Islam.

\section{B. Implikasi Hukum Nikah Siri, Nikah Online dan Talak Siri}

a. Implikasi Hukum Nikah Siri

Nikah siri yang terjadi di Indonesia, ada yang berpandangan dibolehkan dalam perspektif fikih, apabila telah terpenuhi rukun dan syaratnya, tetapi akad ini dapat menimbulkan dampak atau akibat hukum yang merugikan pada suami dan terutama istri dan anak-anaknya. Kedudukan isteri dalam perkawinan siri menurut hukum positif atau Undang-Undang Nomor 1 Tahun 1974 tentang Perkawinan dan juga dalam Kompilasi Hukum Islam, tidak dikenal dan tidak diakui dalam negara, maka perkawinan tersebut tidak mempunyai hak perlindungan hukum.

Perkawinan siri tidak memiliki kekuatan hukum karena perkawinannya tidak dicatat atau tidak dilaksanakan di hadapan Pegawai Pencatat Nikah. Perkawinan siri bahkan dianggap sebagai suatu pelanggaran, sebagaimana terdapat dalam Pasal 45 Peraturan Pemerintah Nomor 9 Tahun 1975. Persoalan akan muncul ketika perkawinan yang telah sah (memenuhi rukun dan syarat perkawinan menurut agama Islam), akan tetapi tidak dicatatkan pada lembaga pencatatan negara, biasanya akan timbul banyak masalah setelah perkawinan. Tidak dapat dipungkiri perkawinan siri menjadi akan membawa petaka dan berdampak negatif karena hukumnya tidak terpenuhi.

Apabila dikaji lebih lanjut, perkawinan bukan hanya mengikat hubungan antara seorang laki laki sebagai suami dan seorang perempuan sebagai istri, namun mempunyai konsekuensi yang luas. Bukan hanya kepada suami dan istri saja, namun dapat berdampak kepada anak dan keluarga besarnya secara psikologis dan sosial. Pernikahan siri atau pernikahan yang tidak tercatat menimbulkan akibat hukum dan ekses pada beberapa pihak yang terkait.

Secara hukum Perkawinan siri berdampak sangat merugikan bagi isteri dan perempuan di antaranya a) Istri tidak dianggap sebagai istri sah; b) Istri tidak berhak atas nafkah dan warisan dari suami jika istri meninggal dunia; c) Istri tidak berhak atas harta gono-gini jika terjadi perceraian, karena secara hukum perkawinan tersebut dianggap tidak pernah terjadi. Sedangkan secara sosial istri akan sulit bersosialisasi karena perempuan yang melakukan perkawinan siri atau perkawinan di bawah tangan 
ini sering dianggap telah tinggal serumah dengan laki-laki tanpa ikatan perkawinan atau isteri tersebut dianggap menjadi isteri simpanan.

Akibat hukum yang lain dari perkawinan siri terhadap anak adalah anak tidak dapat mengurus akta kelahiran. Hal itu dapat dilihat dari permohonan akta kelahiran yang diajukan kepada Kantor Catatan Sipil. Salah satu syaratnya, harus menunjukan akta nikah orang tua anak tersebut. Dalam pasal 5 Undang-Undang Nomor 23 Tahun 2002 Tentang Perlindungan Anak menyebutkan: "Setiap anak berhak atas suatu nama sebagai identitas diri dan status kewarganegaraan". Maka di dalam akta kelahiran anak itu statusnya dianggap sebagai anak luar nikah, tidak tertulis nama ayah kandungnya dan hanya tertulis ibu kandungnya saja. Keterangan berupa status sebagai anak luar nikah dan tidak tercatatnya nama ayah akan berdampak negatif secara sosial dan psikologis bagi anak dan ibunya.

Ali Uraidy mengungkapkan akibat-akibat hukum dari perkawinan siri di antaranya:

1) Tidak adanya kekuatan hukum yang tetap terhadap legalitas perkawinan tersebut, sehingga apabila adanya hak-hak istri yang dilanggar oleh suami, istri tidak dapat menuntut hak-hak tersebut secara hukum;

2) Akad nikah yang dilakukan cenderung tidak dapat dibuktikan secara hukum dan suami istri yang melaksanakan akad nikah siri tidak dapat membuktikan bahwa keduanya merupakan pasangan yang legal di mata hukum Islam maupun Negara;

3) Kepentingan-kepentingan suami istri lainnya dalam menjalani kehidupan berumah tangga tidak dapat dilindungi;

4) Karena tidak ada bukti adanya perkawinan tersebut, kepentingan seperti terkait dengan pembuatan Kartu Tanda Penduduk (KTP), Kartu Keluarga (KK), Pasport maupun Akta kelahiran.

5) Akad nikah siri cenderung membuat salah satu pasangan, khususnya suami lebih leluasa untuk meninggalkan kewajibannya, bahkan berpotensi melakukan KDRT (Kekerasan Dalam Rumah Tangga).

6) Akad nikah siri dapat berakibat mempengaruhi kemaslahatan psikologis istri dan anak, mereka pun merasa tidak nyaman dan tidak tenang;

7) Akad nikah siri dapat berakibat mempengaruhi kemaslahatan agama, jiwa akal, keturunan dan harta.

\section{b. Implikasi Hukum Nikah Online}

Berbicara nikah online, dalam hukum Islam dan Undang-Undang Perkawinan tidak ditemukan aturan yang secara eksplisit menjelaskan dan mengatur tentang hal ini. Dalam konteks keabsahan nikah onlinenya, atau bahkan dalam penerapan pencatatan nikahnya bagi mereka pelaku nikah online. Dengan demikian dapat dipahami bahwa terdapat kekosongan hukum yang berlaku di Indonesia saat ini, dalam hal hukum positif di Indonesia. Dalam pencatatan nikah bagi nikah online, pada dasarnya hal ini erat kaitannya dengan legal hukum suatu akad nikah online. 
Penerapan pencatatan nikah bagi mereka yang melaksanakan akad nikah online ini erat kaitannya dengan peristiwa penting lainnya. Dalam hal ini, terkait legalitas dan pengakuan secara administratif dari Negara terhadap mereka yang melaksanakan pernikahan lewat online. Undang Undang RI. No. 1 Tahun 1974, Pasal 2 Ayat 2 menyebutkan bahwa tiap-tiap perkawinan di catat menurut peraturan perundangundangan yang berlaku. Dan pada KHI Pasal 5 ayat (1) dijelaskan bahwa agar terjamin ketertiban perkawinan bagi masyarakat Islam setiap perkawinan harus dicatat.

Terkait dalam hal pencatatan nikah terhadap nikah online, hal ini tak bisa terlepas dengan peraturan perundang-undangan, yang menuntut dan menjamin bahwa perkawinan adalah sah, apabila dikakukan menurut hukum masing-masing agamanya dan keperayaannya itu. Pernikahan online masih menjadi isu hangat yang terjadi sampai saat ini, hal ini terkait dengan keabsahannya di dalam hukum Islam. Problematika ini komplek karena adanya perbedaan pandangan mengenai keabsahan nikah online menurut hukum agama. Hal ini terkait dengan diskursus implikasi pada penerapan pencatatan nikah di Indonesia. Hal tersebut bermakna ketika nikah online ini diterima dan dianggap sah oleh agama, maka mutlak hukum Negara menerima dan memfasilitasi penerapan pencatatan nikahnya, hal ini sebagai impact atau implikasi dari hukum nikah online sebagaimana terkait dalam bunyi KHI Pasal 4 perkawinan adalah sah, apabila dilakukan menurut hukum Islam sesuai dengan UU No. 1/1974 Pasal 2 (1), bahwa perkawinan adalah sah, apabila dilakukan menurut hukum masingmasing agamanya dan keperayaannya itu.

Konteks ini pula, menjadi suatu implikasi kemutlakan dalam hal penerapan hukum pencatatan nikah, karena tentunya sebagai Negara hukum, maka suatu kepatutan dalam pelaksanakan perkawinan berdasarkan peraturan yang berlaku. Hal tersebut tertera dalam Undang Undang RI. No. 1 Tahun 1974 Tentang Perkawinan, pasal 2 ayat 2 yang berbunyi: "Tiap-tiap perkawinan dicatat menurut peraturan perundangundangan yang berlaku."

Berdasarkan penjelasan tersebut dapat dipahami bahwa dasar dari administrasi nikah dalam hal ini penerapan pencatatan nikah sebagai implikasi nikah online bagi masyarakat yang beragam Islam adalah berdasarkan pada penjelasan dari UU No. 1/1974 Pasal 2 ayat (2), dan KHI Pasal 5 ayat (1). Dalam penerapan pencatatan nikah terhadap implikasi nikah online, sejatinya pihak Kantor Urusan Agama di Indonesia dapat mempertimbangkan pencatatan pernikahan online, dengan dasar syarat-syarat pernikahan telah dipenuhi daan tidak terdapat halangan perkawinan menurut undangundang.

Jika bersandar pada bunyi pasal 6 ayat (3) tersebut sejatinya pihak Pencatat Nikah dapat memberikan kebijakan tentang pelaksanaan nikah online tersebut, apalagi pada masa pandemic Covid 19 ini. Pertimbangan lain pula, bahwa Undang-Undang sampai saat ini tidak ada yang menjelaskan dan bahkan melarang pelaksanaan nikah online. Demikian artinya bahwa selama tak ada Undang-Undang yang secara eksplisit menyebutkan nikah online itu tidak diperbolehkan untuk dilaksanakan, maka nikah online itu dapat dipertimbangkan untuk diakui oleh Negara, asalkan syarat dan rukunnya telah terpenuhi. 


\section{c. Implikasi Hukum Talak Siri}

Talak adalah lepasnya ikatan perkawinan antara suami dan istri, atau diistilahkan dengan perceraian. Dalam ketentuan Agama Islam bahwa yang diinginkan adalah menjaga keharmonisan dan keutuhan bahtera rumah tangga. Talak merupakan alternatif terakhir yang diambil, setelah melalui proses yang panjang, termasuk mendamaikan kedua belah pihak, suami dan istri. Talak diibaratkan sebagai pintu darurat apabila kedua belah pihak, sukar dan tidak dapat lagi menjaga keutuhan rumah tangganya. Menilik makna hadis Rasulullah saw. bahwa talak adalah perbuatan yang halal tapi dibenci oleh Allah swt.

Di sisi lain, terdapat hadis Rasulullah SAW., yang maknanya : ada tiga hal yang dilakukan, kesungguhannya dianggap serius dan ketidaksungguhannya (bercanda) juga dianggap serius, yaitu : nikah, talak dan rujuk. Ulama berbeda paham menyikapi makna hadis tersebut. Ada yang berpandangan bahwa talak tetap jatuh apabila diucapkan dalam keadaan sadar, sengaja maupun bercanda atau berkelakar.

Pandangan ulama di Indonesia menyatakan bahwa talak yang dijatuhkan seorang suami kepada istrinya, baik sengaja maupun dalam keadaan bercanda, maka tidak dikategorikan sebagai talak dan tidak mempunyai konsekuensi hukum, apabila tidak diikrarkan di depan sidang Pengadilan Agama. Hal tersebut berdasarkan kajian yang mendalam seta mempertimbangkan beberapa aspek terkait kemaslahatn suami, istri dan keluarganya. Di antaranya dengan merujuk kepada metodologi hukum Islam, al Maslahat al Mursalah dan Sadd al Zari'ah .

Talak Siri atau perceraian yang tidak tercatat, diketahui bahwa ikrar talak yang diucapkan oleh seorang suami kepada istrinya tanpa melalui proses di Lembaga Negara, Kantor Pengadilan Agama. Hal tersebut bertentangan dengan Pasal 115 Inpres RI No. 1 Tahun 1991 Tentang Kompilasi Hukum Islam. Bahwa perceraian hanya dapat dilakukan di depan sidang Pengadilan Agama. Di sisi lain, dipahami bahwa Materi Kompilasi Hukum Islam adalah hasil Ijma'(kesepakatan) Ulama Indonesia lingkup Hukum Islam, terkait dengan materi Perkawinan, Kewarisan dan Wakaf. Inilah yang menjadi salah satu rujukan para hakim agama dalam memutuskan perkara di Kantor Pengadilan Agama.

\section{KESIMPULAN}

Nikah siri yang tidak tercatat pada Kantor Urusan Agama dan talak siri yang tidak tercatat pada Pengadilan Agama berimplikasi pada kedudukan istri dan anak yang tidak diakui oleh negara, tidak dapat mewarisi antar ayah dan anak, serta istri tidak mendapatkan harta gono gni setelah cerai dan banyak dampak yang lebih besar ditimbulkan dari nikah siri dan talak siri. Dengan merujuk kepada metodologi Hukum Islam, konsep Maslahah Mursalah dan Sadd al Zari'ah, perbuatan nikah siri dan talak siri dianggap bertentangan karena memberikan dampak buruk yang lebih besar kepada suami, istri dan keluarganya. Demikian juga bertentangan dengan Undang 
Undang RI. No 1 Tahun 1974 Tentang Perkawinan serta Inpres RI. No. 1 Tahun 1990 Tentang Kompilasi Hukum Islam. Sedangkan nikah online yang memanfaatkan teknologi informasi, meskipun tidak diatur secara eksplisit dalam peraturan perundang undangan, namun apabila rukun dan syaratnya terpenuhi maka dapat dikategorikan sahnya suatu pernikahan dan dapat dipertimbangkan untuk didaftar dan dicatatkan pada Petugas Pencatat Nikah (PPN) di Kantor Urusan Agama (KUA).

\section{DAFTAR PUSTAKA}

Andi Muhammad Akmal, Asas Maslahat Pencatatan Nikah dalam Mereformulasi Fikih Nikah (Analisis dengan Pendekatan Ushul Fikih), Disertasi PPS UIN Alauddin Makassar, Tahun 2013.

Al-Qurahdaghi, Muhyiddin. 2003. Fiqih Digital. Yogyakarta: Qonun-Prisma Media.

Askar, S. 2009. Kamus Al-Azhar. Jakarta: Senayan Publishing.

Basyir, Ahmad Asyhar. 2014. Hukum Perkawinan Islam, Yogyarkata, UII Pres.

Daniar Syamdan, Addin. "Aspek Hukum Perkawinan Siri dan Akibat Hukumnya" Notarius 12. No. 1 (2019)

Dewan Redaksi Ensiklopedi Islam. 1994. “Nikah”, Ensiklopedi Islam Jilid 4. Jakarta: PT. Ichtiar Baru Van Hoenev.

Djubaidah, Neng. 2016. Pencatatan Perkawinan \& Perkawinan Tidak Dicatat Menurut Hukum Tertulis di Indonesia dan Hukum Islam. Jakarta: Sinar Grafika, 2016.

Farid, Miftah. "Nikah Online dalam Perspektif Hukum”, Jurnal Ilmu Hukum Fakultas Syari' ah dan Hukum. Vol. 5 No.1 (2018)

Islami, Irfan. "Perkawinan Di Bawah Tangan (Kawin Siri) dan Akibat Hukumnya", ADIL: Jurnal Hukum 8. No.1 (Desember 208).

Jayadi, A. 2012. Fenomena Nikah Siri Perspektif Makna Pelaku Siri. Surabaya: Putra Media Nusantara, 2012.

Kementrian Pendidikan dan Kebudayaan, Kamus Besar Bahasa Indonesia, http://ebsoft.web.id (05 Mei 2021)

M. Zein, Satria Effendi. 2010. Problematika Hukum Keluarga Islam Kontemporer, Cet. 111, Jakarta, Kencana.

MK, Anshari. 2010. Hukum Perkawinan di Indonesia, Masalah-Masalah Krusial. Yogyakarta: Pustaka Belajar. 
Muhdhar, M. Zuhdi. 2000. Memahami Hukum Perkawinan: Nikah, Talak dan Rujuk Menurut Hukum Islam UU No. 7 Tahun 1989, dan KHI di di Indonesia. Bandung: Al-Bayan.

Muhdhar, M. Zuhdi. 2000. Memahami Hukum Perkawinan: Nikah, Talak, dan Rujuk menurut Hukum Islam UU No. 7 Tahun 1989, dan KHI di Indonesia. Bandung: AlBayan.

Muthiah, A. 2017. Hukum Islam Dinamika Seputar Hukum Keluarga. Yogyakarta: Pustaka Baru Press.

Nur, Djamaan. 1993. Fiqih Munakahat. Semarang: CV. Toha Putra Group.

Nurhaedi, Dedi. 2003. Nikah di Bawah Tangan. Yogyakarta: Saujana.

Ramulyo, Mohammad Idris. 1996. Hukum Perkawinan Islam Suatu Analisis dari UU No.1 tahun 1974 dan Kompilasi Hukum Islam. Jakarta: BUMI AKSARA.

Rasyid, Sulaiman. 2001. Fiqh Islam. Jakarta: ttp.

Ratnawaty, Latifah. "Kedudukan Nikah Sirri Menurut Hukum Positif di Indonesia" Yustisi 2. No. 2 (September 2015).

Republik Indonesia, Undang-Undang Republik Indonesia Nomor 16 Tahun 2019 tentang Perubahan Atas Undang-Undang Nomor 1 Tahun 1974 Tentang Perkawinan.

Sobari, A. "Nikah Siri Dalam Perspektif Islam" Mizan: Jurnal Ilmu Syariah 1. No. 1 (2013).

Soemiyati. 1982. Hukum Perkawinan Islam dan Undang-Undang Perkawinan (UndangUndang Nomor 1 Tahun 1974 Tentang Perkawinan). Yogyakarta: Liberti.

Supriatna dkk. 2008. Fiqh Munakahat II Dilengkapi Dengan UU No I/1974 dan Kompilasi Hukum Islam. Cet. I. Yogyakarta: Bidang Akademik UIN Suka.

Susanto, Happy. 2007. Nikah Siri Apa Untungnya?. Jakarta: Visimedia.

Syarifuddin, Amir. 2006. Hukum Perkawinan Islam di Indonesia. Jakarta: Kencana, Pranadamedia Group.

Thalib, Sayuti. 1974. Hukum Kekeluargaan Indonesia. Jakarta: UI Pres, 1974.

Tim Penulis Departemen Pendidikan dan Kebudayaan. 1989. Kamus Besar Bahasa Indonesia. Jakarta: Balai Pustaka.

Uraidy, Ali. "Pekawinan Siri dan Akibat Hukumnya Ditinjau dari Undang-Undang No. 1 Tahun 1974". Fenomena 10. No. 2 (November 2012) 